\title{
Feeding trials in organic food quality and health research
}

\author{
Alberta Velimirov ${ }^{a *}$ Machteld Huber, ${ }^{b}$ Charlotte Lauridsen, ${ }^{c, g}$ \\ Ewa Rembiałkowska, ${ }^{d}$ Kathrin Seidel $^{\mathrm{e}}$ and Susanne Bügel ${ }^{\mathrm{f}, \mathrm{g}}$
}

\begin{abstract}
Feeding experiments comparing organically and conventionally produced food are performed to assess the overall impact on the animals' health as a model for the effects experienced by the human consumers. These experiments are based on systems research and characterized by their focus on production methods, whole food testing and procedures in accordance with the terms of organic farming. A short review of such experiments shows that the majority of these tests revealed effects of the organically produced feed on health parameters such as reproductive performance and immune responses. Systems research is not just about simple cause-effect chains, but rather about the pluralism of interactions in biological networks; therefore, the interpretation of the outcome of whole food experiments is difficult. Furthermore, the test diets of organic and conventional origin can be constituted in different ways, compensating for or maintaining existing differences in nutrient and energy contents. The science-based results suggest positive influences from organic feeds, but there is still a need for confirmation in animals and, finally, in humans. For this purpose animal feeding trials with feed from different production systems should be conducted, with the aims to define health indicators and to establish biomarkers as a basis for future dietary intervention studies in humans.
\end{abstract}

(c) 2009 Society of Chemical Industry

Keywords: feeding trials; organic feed; health effects; biomarkers

\section{INTRODUCTION}

Organic agriculture as defined in the EU regulation (EC) No. $834 / 2007$ does not use synthetic fertilizers and pesticides, but it is not 'just without' these substances. Organic agriculture optimizes production, through modern farming management skills, along with maintaining the inborn capacity of plants and animals to be healthy without addition of synthetic pesticides and antibiotics. The aim is to create an ecologically balanced system on the farm at its specific location. Organic farm management does not follow one set of rules, but is an individualized skilled application of general principles. It has previously been shown that organic agriculture is advantageous for soil fertility, ${ }_{1}$ for biodiversity, ${ }^{2}$ for sustainability ${ }^{3,4}$ and for animal welfare and health. ${ }^{5}$ The vision as stated by Lady Balfour, ${ }^{6}$ the founder of the Soil Association in 1946 - 'Healthy soil, healthy plants, healthy people' - can still be regarded as the key note of organic farming.

Consumers expect organic foods to be healthier than conventionally produced foods, ${ }^{7}$ but so far, research has not been able to prove this. The International Research Association for Organic Food Quality and Health, (FQH) aims to investigate and develop a scientific conceptual basis for organic food quality, as well as novel methods to examine food quality and to study the influence of organic food on human health. ${ }^{8}$ The association consists of research institutes that connect in their activities to these objectives and researchers of these institutes work together to attain these aims.

The aim of this paper - by authors who are all representatives of member institutes of $\mathrm{FQH}$ - is to describe the state of the art of animal experiments used for comparing the impact on health and preference of organically and conventionally produced food. Furthermore, necessary criteria for animal feeding experiments that do justice to the concepts of organic agriculture are clarified.

Little is known about possible physiological effects of organic food in humans due, in part, to the lack of clear health biomarkers. Therefore, animal feeding experiments are warranted, aiming at identification of biomarkers suitable for human intervention studies. The animal studies described in this paper have focused on the possible differences between the consumption of products from modern conventional and certified organic production and from organic or mineral fertilizer regimes. This paper is focused

* Correspondence to: Alberta Velimirov, FiBL Austria, Seidengasse 33-35, A-1070 Wien, Austria.E-mail:alberta.velimirov@fibl.org

a FiBL, Research Institute of Organic Agriculture, Vienna, Austria

b Louis Bolk Institute, Driebergen, The Netherlands

c Department of Animal Health, Welfare and Nutrition, University of Aarhus, Aarhus, Denmark

d Warsaw University of Life Sciences, Warsaw, Poland

e FiBL, Research Institute of Organic Agriculture, Frick, Switzerland

f Department of Human Nutrition, University of Copenhagen, Copenhagen, Denmark

g Representatives of Danish Centre of Organic Farming and Food Systems, Foulum, Denmark 
on scientific studies, mainly performed on laboratory animals, not on differences in the health status of farm animals in organic and conventional production systems.

The described animal experiments have the purpose of using animals as models for humans. In the field of nutrition in general, experimental animals are either used to assess the risk of toxic food substances, or to prove beneficial effects of certain food additives and components, or more generally to study physiological aspects such as absorption, metabolism, and function of nutrients. The findings from animal studies can be used as guidelines for humans, although the extrapolation of animal results to humans has to be done with great care.

Epidemiological studies have repeatedly shown that high intake of fruits and vegetables decrease the risk of lifestyle-related diseases and increase longevity. ${ }^{9-13}$ These beneficial effects are attributed to bioactive phytochemicals as well as vitamins, trace elements and fibres.

In both cases, testing negative effects of toxic substances or positive effects of health-promoting nutrients, the focus is on the investigation of single cause-effect chains. But in the context of organic agriculture and food quality research, including feeding experiments, the epistemological background is based on the holistic perception of systems. Thus, a whole food product is not reduced to a set of chemicals, but is seen as a dynamic, hierarchically organized unit in which short linear cause-effect chains are modulated by synergistic, additive and reductive interactions. Foods can have effects that are not traceable to the components, but emerge from the interaction of these components. This notion is well expressed by the dictum: 'The whole is more than the sum of the parts.' Differences between the effect of single compounds and whole products have been shown in several intervention studies. ${ }^{14-19}$ Living organisms, concerning agricultural foods in the context of nutrition, (self-)organize the contained compounds ideally into a homeostatic status. ${ }^{20}$ Organic agricultural research is based on the hypothesis that the coherence of this organizational structure is influenced by production measures. This production-dependent intrinsic property or 'inner order' might have an impact on health and account for feeding trial outcomes irreducible to the chemical composition of the test diets. The consequence for the animal feeding design connected to organic agriculture is the use of whole foods, not purified diets.

The focus of this paper is on plant-derived feeds, since, so far, mainly organically produced crops have been investigated in feeding trials.

\section{FEEDING EXPERIMENTS IN ORGANIC FOOD QUALITY RESEARCH}

From the described holistic perspective in organic agriculture, research concerning food quality and connected health effects should not exclusively rely on the composition data of the food, but also characterize the food products by a more comprehensive view of food quality. This could be based on systemic properties like integrity, inner order and 'inner quality', referring to aspects of an organizational structure which cannot be explained solely out of its components. Several holistic methods aiming to measure these quality aspects are currently in a process of standardization and validation (e.g., low-level luminescence and biocrystallization). ${ }^{21,22}$ Likewise, feeding experiments in organic quality research are performed to assess the overall effect of differently grown feeds on animals' health.
These experiments are characterized by the following features:

- focus on production method;

- whole food testing;

- procedures in accordance with the terms of organic farming.

\section{Focus on production methods}

The aim of the comparative feeding experiments described herein is to reveal food effects, e.g. on general health, eating behaviour, breeding performance and immune reactions, that can be traced back to production methods. This represents a new approach currently only used in organic quality research.

The flexibility within the regulatory framework is lower in organic as compared with conventional agriculture, where the range of quality produced stretches from almost organic, but not certified, to industrial, with the highest external inputs at present. Therefore, in such comparative studies the way the different foodstuffs have been produced has to be described in detail. In some studies factorial field trials are used to control all growing conditions and to emphasize the potential impact of defined applications: for instance, fertilization and/or plant protection. The advantage of comparing products from operating farms in the 'farm-pair approach' is the simultaneous inclusion of many additional factors such as crop rotation, intercropping, soil quality depending on long-standing treatments and management skills. Although this approach is very complex, it pays tribute to the notion that organic farming is an individualized application of general principles. In this case the conventional products have to originate from neighbouring farms with the same soil and climatic conditions and should reflect region-typical farming methods. Both approaches are important contributions to quality assessments: feeding tests based on factorial field trials are important for basic research, whereas farm-pair comparisons reflect realistic conditions and are, therefore, of more interest for the consumer.

So far, the scientific approach has been to compare the same diet composition of the same cultivars. But one important feature in organic farming is the recognition of the necessity to use varieties adapted to the specific organic conditions of fertilizing, ${ }^{23}$ next to the aims to reintroduce old varieties to conserve genetic resources and to offer more taste diversity. Therefore, in a systems-oriented feeding design, the use of different cultivars as typical of the respective cultivation system can also be introduced.

\section{Whole food testing}

The epistemological background of whole food trials postulates - as mentioned before - that single components consumed as an integrated part of the food could act differently as compared to results obtained from testing the isolated compound.

Concerning the test feed preparation, two approaches are used: either all or the main nutrient differences are levelled by adding the lacking components to both diets, or existing compositional differences are preserved and seen as intrinsic quality differences, thus being part of the study design. The latter approach involves the entire food system by accepting compositional differences as cultivation-inherent properties reflected in different feed effects. It should be taken into account that deficiencies should be avoided as these can confound results. Since the analytical differences of main nutrients between conventional and organic products are generally low, both variants can be expected to fulfil the metabolic needs of the test animals.

The influence of the feed-processing steps on cultivationdependent quality parameters must be taken into account if 
cultivation is the main focus. Intensive processing such as the use of heat, pressure and freeze drying might denature structures, thus possibly obliterating primary production-dependent differences.

However, processing steps may have beneficial effects on digestibility and availability of health-promoting compounds (e.g., lycopene in tomatoes) ${ }^{24}$ and could be tested in a dietary intervention design where the primary focus is on processing. Feeding trials with differently processed food, either conventionally or organically, are still rare in the field of organic quality research, ${ }^{25}$ but there is increasing demand for such studies to define and optimize organic processing methods. Pesticide residues should be under the safety limits to reflect realistic conditions. Questions about harmful effects from pesticides require separate focused research designs.

The interpretation of results from feeding trials, where the test diets were comparable in nutrient contents, poses a challenge which needs special attention.

Williams ${ }^{26}$ remarks that the very small differences in nutrient contents of crops grown under the two systems (organic and conventional) would be very unlikely to provide a nutritional basis for the differences in reproductive performance or immune reaction in these animals. Therefore, new hypotheses regarding systemic topics are needed, which could result from the development of holistic quality parameters and be measured in a descriptive way or in phenomenological observations. But phenomenological observations, although playing a valid role in science, do not replace the need for understanding and relating the findings to underlying principles. Biological systems are complex systems, still barely understood, especially concerning the influence of nutrients on gene expression affecting metabolic pathways.

The current approach of systems biology-analysing small segments and developing data integration models to elucidate complex interaction networks - relies on the notion that welldesigned experiments will eventually lead to an understanding of them all. Possibly, several key functions can be isolated, valued separately and then used for a joint single score upon which the quality assessment can be based. ${ }^{27}$ On the other hand, results from holistic quality assessment methods based on a property, reflecting the overall performance, could provide more meaningful answers than analytical trait scoring.

\section{Procedures in accordance with the terms of organic farming}

Apart from the systemic approach, 'organic' feeding trials should be conducted in agreement with the principle of ethics implemented in the organic movement (IFOAM principles: health, fairness, ecology and care; http://www.ifoam.org/about_ifoam/ principles/index.html). These principles include the avoidance of painful procedures, the opportunity for the animals to have social contacts and the use of adequate feed according to the test animals' nutritional needs. Thus beneficial and negative health effects should be linked to quality differences alone and not to stress and/or nutritional inadequacy.

\section{VARIABLES AND PARAMETERS INVESTIGATED IN HEALTH RESEARCH ON ORGANIC FOOD}

The variables investigated in comparative feeding studies comprise feeding behaviour and consumption, fertility parameters, as well as biomarkers of health, e.g. weight gain and growth, blood parameters, immune status, organ function and post-mortem analyses.

Feeding experiments with laboratory animals are routinely used in toxicology and nutritional research, but in the context
Table 1. Different approaches of feeding trials in nutritional research

\begin{tabular}{|c|c|c|}
\hline Variables & Approach 1 & Approach 2 \\
\hline Type of trial & $\begin{array}{l}\text { Animal experiment (subject } \\
\text { of authorization) }\end{array}$ & $\begin{array}{l}\text { Animal experiment } \\
\text { (subject of registration) }\end{array}$ \\
\hline Test object & Single compound & Whole food \\
\hline Type of effect & Linear (dose dependent) & $\begin{array}{l}\text { Synergistic (network } \\
\text { dependent) }\end{array}$ \\
\hline Test aim & $\begin{array}{l}\text { Health risk or benefit of test } \\
\text { substance }\end{array}$ & $\begin{array}{l}\text { Health benefits of whole } \\
\text { food }\end{array}$ \\
\hline
\end{tabular}

of investigating potential health effects of organic food the approach has focused on synergistic and additive interactions of whole foods (Table 1).

In the following, feeding trials with different research questions are summarized. The studies used parameters aimed at detecting potentially different effects of organic and conventional production methods, as well as differences in fertilization techniques. Studies from before implementation of the EU regulations on organic agriculture are included, as they may contribute to indications about where to look for physiological effects.

\section{The influence of different fertilizing and processing methods}

The first feeding trials focusing on production methods were conducted in the 1930s. Their purpose was to compare the effects of biological-dynamical versus mineral fertilizers on product quality and animal health. At that time only biodynamic farming had been regulated (1928). Wöse et al. ${ }^{28}$ give a very comprehensive description of these early endeavours (Table 2 ).

The majority of the studies showed that animals fared better with biodynamic (compost, manure), as compared to minerally fertilized feed, ${ }^{29-34}$ while a few observed no effect. ${ }^{35-37}$

Neudecker ${ }^{37}$ found no differences concerning fertility parameters between the feeding groups. In this case the test products were carrots and potatoes, which were boiled, freeze-dried and pressed into pellets. It could be questioned whether this intensive processing - the use of heat, freezing and pressure - might change primary quality differences in the products. Little research has been done in this area but is worth more focused research. On the other hand, in a still running feeding experiment with rats it has been found that the level of secondary plant compounds (polyphenols and carotenoids, in four replicates) was significantly higher in the processed rat feed obtained from the organic crops compared to rat feed based on the conventional crops. This means that higher nutritive value of the fresh crops obtained from the organic cultivation had not been changed during the processing procedure, which observed temperatures below $50{ }^{\circ} \mathrm{C} .^{38}$

\section{The influence of farming systems}

Gottschewski's ${ }^{39}$ feeding experiment with rabbits was among the first investigating food from different farming systems as opposed to different fertilizing methods. He used feed which was produced according to the biodynamic regulations, established in 1928 as certified Demeter quality. His findings were later corroborated by two more rabbit experiments, observing significantly better rearing successes due to fewer perinatally dead and more weaned pups in combination with a superior weight development in the organically fed rabbits. ${ }^{40,41}$ The feed in the two latter projects was produced according to the national regulation for organic agriculture in Austria, established in 1983. 
Table 2. Overview feeding experiments with different fertilizer applications (adapted from Wöse et al. ${ }^{28}$ )

\begin{tabular}{|c|c|c|c|c|c|}
\hline Author & Objective & Feed & Animal & Assessed parameter & Results \\
\hline McCarrison (1926) & $\begin{array}{l}\text { Cow dung vs. mineral } \\
\text { fertilizer (NPK) }\end{array}$ & Wheat & Rats & Growth rate & $\begin{array}{l}\text { Rats fed with wheat } \\
\text { grown with cow dung } \\
\text { showed better growth } \\
\text { rate after } 72 \text { days } \\
\text { (22.5\% more weight) }\end{array}$ \\
\hline Pfeiffer (1931) & $\begin{array}{l}\text { Biodynamic vs. mineral } \\
\text { fertilizer }\end{array}$ & Wheat & Mice & Pup survival rate & $\begin{array}{l}\text { Until the 9th week about } \\
50 \% \text { more pups } \\
\text { survived when fed } \\
\text { with biodynamic } \\
\text { fertilized wheat } \\
\text { (biodynamic, } 8.6 \% ; \\
\text { mineral, } 16.9 \% \text { ) }\end{array}$ \\
\hline Pfeiffer and Sabarth (1932) & $\begin{array}{l}\text { Biodynamic vs. mineral } \\
\text { fertilizer }\end{array}$ & Wheat & Chicken & Egg production & $\begin{array}{l}7 \text { months: org. } 121.3 \text { vs. } \\
\text { min. } 97.7 \text { eggs } \\
9 \text { months: org. } 192 \text { vs. } \\
\text { min. } 150 \text { eggs } \\
\text { hatching: org. } 68 \% \text { vs. } \\
\text { min. } 35 \% \text { eggs with } \\
\text { chicks }\end{array}$ \\
\hline Scheunert (1935) & $\begin{array}{l}\text { Unfertilized vs. mineral } \\
\text { fertilizer }\end{array}$ & $\begin{array}{l}\text { Cereals, vegetables, milk, } \\
\text { beef }\end{array}$ & Rats & Reproduction & $\begin{array}{l}\text { Mineral: larger litters } \\
\text { Unfertilized: better } \\
\text { survival rate }\end{array}$ \\
\hline Miller and Dema (1958) & $\begin{array}{l}\text { Unfertilized vs. dung vs. } \\
\text { mineral fertilizer }\end{array}$ & Wheat & Rats & Growth rate & No difference \\
\hline Aehnelt and Hahn (1965) & $\begin{array}{l}\text { Cow dung vs. mineral } \\
\text { fertilizer }\end{array}$ & Hay & Bulls & Fertility & $\begin{array}{l}\text { Cow dung: better semen } \\
\text { motility }\end{array}$ \\
\hline Aehnelt and Hahn (1973) & $\begin{array}{l}\text { Biodynamic vs. mineral } \\
\text { fertilizer }\end{array}$ & Hay, carrots, kohlrabi & Rabbits & Fertility, organ-centred & $\begin{array}{l}\text { All fertility parameters } \\
\text { better with } \\
\text { biodynamic (ovulation } \\
\text { points, fertilized eggs, } \\
\text { weight of ovaries) }\end{array}$ \\
\hline Bram (1974) & $\begin{array}{l}\text { Biodynamic vs. mineral } \\
\text { fertilizer vs. liquid } \\
\text { manure }\end{array}$ & Hay, kale, carrots, kohlrabi & Rabbits & $\begin{array}{l}\text { Cell count and nucleoli } \\
\text { size in adrenal cortex }\end{array}$ & $\begin{array}{l}\text { Group fed with minerally } \\
\text { fertilized products } \\
\text { showed a reduction of } \\
\text { cells and nucleoli size }\end{array}$ \\
\hline Alter (1978) & $\begin{array}{l}\text { Biodynamic vs. mineral } \\
\text { fertilizer vs. liquid } \\
\text { manure }\end{array}$ & $\begin{array}{l}\text { Pasture, hay, kale, kohlrabi, } \\
\text { carrots }\end{array}$ & Rabbits & $\begin{array}{c}\text { Fertility, parameters of } \\
\text { males and females }\end{array}$ & No difference \\
\hline Neudecker (1987) & $\begin{array}{l}\text { Organic vs. mineral } \\
\text { fertilizer }\end{array}$ & $\begin{array}{l}\text { Carrots and boiled potatoes } \\
\text { were freeze-dried and fed } \\
\text { as pellets }\end{array}$ & Mice, rats & $\begin{array}{c}\text { Fertility, parameters of } \\
\text { males and females }\end{array}$ & No difference \\
\hline
\end{tabular}

Very similar results could be obtained when feeding laboratory rats with organic versus conventional feed. ${ }^{42}$ Again, in the organic group significantly fewer offspring were stillborn, or died within the first week of their lives; the survival rate until weaning time at the age of 28 days and the weight development were slightly higher, and also the weight gain of the female rats in connection with litter size and pup weight during lactation was significantly higher. In this case the diets were supplemented up to the same nutritive quality. Any primary differences were adjusted by the addition of trace elements, minerals and vitamins. The basic diet was pelleted, but next to this fresh carrots and common beets were apportioned daily. This suggests that measuring the main nutrient concentrations does not suffice in predicting health effects.

Table 3 provides an overview of feeding experiments with a systemic approach.

\section{In search for health biomarkers}

In a recent study of three generations of rats, the objective was to define which measurable aspects of health (if any) would be most affected by differences in production methods, as information for more targeted future studies (Table 4). ${ }^{43}$ Three iso-energetic and iso-nitrogenous diets composed of vegetables and a high content of rapeseed oil (13\%) produced according to each of three different cultivation systems were used in the study. The differences between the three diets were three combinations of cultivation strategies used to grow the ingredients: 'Organic' - low input of fertilizer through animal manure and without pesticides; 'Minimally fertilized' - low input of fertilizer primarily through animal manure and with pesticides; 'Conventional' - high input of mineral fertilizer and with pesticides.

Even though the dietary treatments were supplemented until similar in terms of nutritive quality, some notable differences appeared with regard to some of the measured health biomarkers in the rats that have until now not been assayed in similar comparative studies. Among these health-related biomarkers were concentrations of $\alpha$-tocopherol and immunoglobulin $\mathrm{G}$, daytime activity, volume of adipose tissue, liver metabolic function and liver lipid peroxidation. Since the study only contained one replicate 
Table 3. Feeding experiments with feeds from organic versus conventional growing systems

\begin{tabular}{|c|c|c|c|c|}
\hline Author & Feed & Animal & Parameter & $\begin{array}{l}\text { Results for the group with feed } \\
\text { from organic production }\end{array}$ \\
\hline Gottschewski (1975) & $\begin{array}{l}\text { Common beets, hay, oats, carrots, } \\
\text { wheat }\end{array}$ & Rabbits & Reproduction & $\begin{array}{l}\text { Biodynamic, significantly fewer perinatally } \\
\text { dead and more weaned pups }\end{array}$ \\
\hline Edelmüller (1984) & $\begin{array}{l}\text { Potatoes, common beets, barley, oats, } \\
\text { carrots, beet root }\end{array}$ & Rabbits & Reproduction & $\begin{array}{l}\text { More pups born, fewer perinatally dead, } \\
\text { more weaned pups }\end{array}$ \\
\hline Staiger (1986) & $\begin{array}{l}\text { Dried grass meal, wheat, oats, barley, } \\
\text { soy beans }\end{array}$ & Rabbits & Reproduction & $\begin{array}{l}\text { More pups born and weaned, higher } \\
\text { weight at birth and during weaning time }\end{array}$ \\
\hline Plochberger (1989) & $\begin{array}{l}\text { Dried grass meal, wheat, oats, barley, } \\
\text { soy beans }\end{array}$ & Chicken & Egg quality & Significantly higher egg weight \\
\hline Velimirov and Plochberger (1992) & $\begin{array}{l}\text { Barley, oats, soy beans, peas, carrots, } \\
\text { common beets }\end{array}$ & Rats & Reproduction & $\begin{array}{l}\text { Significantly fewer perinatally dead pups, } \\
\text { better weight gain in lactating females }\end{array}$ \\
\hline
\end{tabular}

Table 4. Feeding studies with the aim of defining biomarkers for health effects and disease risk usable for future human studies measuring differences between organic and conventional diets on health effects and disease risk

\begin{tabular}{|c|c|c|c|c|c|}
\hline Author & Objective & $\begin{array}{l}\text { Products integrated in } \\
\text { complete diets }\end{array}$ & Animal & Health biomarkers & Results \\
\hline \multirow[t]{7}{*}{$\begin{array}{l}\text { Lauridsen } \\
\quad \text { et al. (2007) }\end{array}$} & Factorial design & $\begin{array}{l}\text { potatoes, carrots, peas, kale, } \\
\text { apples, rapeseed oil, } \\
\text { freeze-dried }\end{array}$ & Rats & $\begin{array}{l}\text { Clinical health and disease } \\
\text { status }\end{array}$ & $\begin{array}{l}\text { Diet with organic } \\
\text { fertilization/no pesticide: } \\
\text { significantly higher } \\
\text { plasma IG6, vitamin E, less } \\
\text { body fat and more relaxed }\end{array}$ \\
\hline & $\begin{array}{l}\text { Organic fertilization/no } \\
\text { pesticide }\end{array}$ & & & $\begin{array}{l}\text { Bioavailability of nutrients } \\
\text { and metabolism }\end{array}$ & \\
\hline & $\begin{array}{l}\text { Organic fertilization + } \\
\text { pesticide }\end{array}$ & & & Physical activity & \\
\hline & $\begin{array}{l}\text { Mineral fertilization + } \\
\text { pesticide }\end{array}$ & & & $\begin{array}{l}\text { Functions of organs, } \\
\text { intestine }\end{array}$ & \\
\hline & & & & $\begin{array}{l}\text { Analyses of nutritional status } \\
\text { in blood and tissues }\end{array}$ & \\
\hline & & & & $\begin{array}{l}\text { Analysis of immune } \\
\text { response }\end{array}$ & \\
\hline & & & & $\begin{array}{l}\text { Post-mortem evaluation of } \\
\text { organs }\end{array}$ & \\
\hline \multirow[t]{5}{*}{$\begin{array}{c}\text { Barańska et al. } \\
\text { (2007) }\end{array}$} & Factorial design & $\begin{array}{l}\text { Barley, potatoes, carrots, } \\
\text { onions, pellets }\end{array}$ & Rats & $\begin{array}{l}\text { Analyses of immune } \\
\text { response, splenocyte } \\
\text { proliferation }\end{array}$ & $\begin{array}{l}\text { Proliferation of splenocytes } \\
\text { appeared to be }\end{array}$ \\
\hline & $\begin{array}{l}\text { Organic fertilization/no } \\
\text { herbicide }\end{array}$ & & & Feed intake & suppressed with mineral \\
\hline & $\begin{array}{l}\text { Organic fertilization + } \\
\text { herbicide }\end{array}$ & & & Blood morphology & fertilizer inputs, \\
\hline & $\begin{array}{l}\text { Mineral fertilization/no } \\
\text { herbicide }\end{array}$ & & & $\begin{array}{l}\text { Anti-oxidative status of } \\
\text { plasma }\end{array}$ & $\begin{array}{l}\text { significantly higher } \\
\text { anti-oxidative status of } \\
\text { plasma in rats on feeds } \\
\text { without pesticides }\end{array}$ \\
\hline & $\begin{array}{l}\text { Mineral fertilization + } \\
\text { herbicide }\end{array}$ & & & & \\
\hline \multirow[t]{8}{*}{$\begin{array}{l}\text { Huber et al. } \\
\quad(2007)\end{array}$} & $\begin{array}{l}\text { Systems approach: organic } \\
\text { vs. conventional growing }\end{array}$ & $\begin{array}{l}\text { Wheat, barley, triticale, peas, } \\
\text { maize, soy, ground }\end{array}$ & Chickens & $\begin{array}{l}\text { Weight development, } \\
\text { growth }\end{array}$ & $\begin{array}{l}\text { Organically produced feed: } \\
\text { significantly lower weight, }\end{array}$ \\
\hline & systems & & & Feed intake & stronger immune \\
\hline & & & & Clinical health, disease status & responsivity, stronger \\
\hline & & & & Egg production & catch-up growth and liver \\
\hline & & & & $\begin{array}{l}\text { Organ function of different } \\
\text { organs by metabolomics } \\
\text { and genomics }\end{array}$ & metabolism after challenge \\
\hline & & & & Immune responsivity & \\
\hline & & & & Response to a KLH challenge & \\
\hline & & & & Post-mortem evaluation & \\
\hline
\end{tabular}


per cultivation system, it was not possible to extrapolate to the population of organic and conventional foods, but this issue is addressed in an ongoing project (http://www.icrofs.org/).

In another recent study in search of biomarkers, two generations of chickens were fed from two production systems in a farm-pair approach, of which the existing differences in nutritional quality, mainly $10 \%$ more protein in conventional grain, were maintained (Table 4). ${ }^{44}$ The results of this study still await publication, but here differences in weight gain and immune responsivity were found.

Another multigenerational study on rats has been conducted from 2006 within the EU project Quality Low Input Food..$^{45}$ In this study rats were given organic, conventional and two kinds of 'low-input' diets (Table 4). ${ }^{45}$ Splenocyte proliferation was used as a sensitive measure to detect potential impacts of diets on the immune system of rats. The proliferation of splenocytes from adult rats appeared to be suppressed when diets were based on crops grown with mineral fertilizer inputs. This suggested that the immune system of rats fed with organically fertilized diets was probably better prepared to fight against infections. The studies are currently continued. Table 4 shows feeding experiments with the aim of defining health biomarkers.

\section{Feed acceptance, avoidance and preference (food preference} tests)

An integral part of feeding experiments is the feeding behaviour of animals. The quantity of feed intake is regulated by the need to keep up energy homeostasis and also depends on the quality of the feed offered. Thus, if a feed is deficient in any nutrients, more will be consumed. ${ }^{46}$ In natural surroundings animals can choose their feed according to need, which has led to the development of very complex feeding behaviour that enables animals to recognize 'healthy' foods or balanced diets. Food preference tests are based on this nutritive wisdom. The normal diet should be provided during the test to avoid nutrient deficiencies and subsequent behavioural disorder. It has to be kept in mind that in organic quality research the objective is not to investigate dietary specifics but to reveal quality differences depending on production methods.

So far, it has been postulated that for animals to be able to choose, at least one of the offered foods has to be nutritionally unbalanced, otherwise there would be no benefit in choosing. But a number of food preference tests conducted with different animals have shown that even in cases of no analytically apparent imbalances significant preferences have taken place when the test variants originated from different cultivation systems. ${ }^{47,48}$

Similar to most of the above-mentioned feeding experiments, the first food preference tests were also conducted with products grown with different fertilizers. Laboratory mice significantly preferred organic as compared to mineral-fertilized wheat. ${ }^{49}$ Later on, food preference tests were concerned with comparing products from organic and conventional production systems. Rabbits and chicken were both capable of distinguishing between differently grown feed and significantly preferred organic common beets, potatoes and cereals over the conventional variants. ${ }^{40,50}$ Since the 1990s, a number of food preference tests have been carried out with laboratory rats displaying a manifold and flexible feeding behaviour. The instinctive diet selection of laboratory rats can give valuable information about food quality that, so far, cannot be obtained from traditional laboratory techniques. ${ }^{51}$ Thus products with no significant content differences were still differentiated on highly significant levels by the rats. ${ }^{52}$
The limitations of the method are determined by inborn taste preferences, e.g. for sweet taste and aversions, such as against bitter or sour. To make the full use of the deep-rooted and welldeveloped feeding behaviour, it is preferable to test foods that wild rats would sample. Furthermore, individual products should be offered, not whole diets, again simulating natural conditions as closely as possible.

Food preference tests with laboratory rats have also been used to investigate whether they are capable of differentiating whole diets composed of differently grown products. ${ }^{53}$ In this study the influence of the mother's diet on food choice could be corroborated, but the choices were different from one individual to another and were changed from one day to another. Thus a preference for organic food could not be established on a significant level. This could be due to offering complete diets instead of single raw products, where post-ingestive consequences are more easily attributed to the test food.

Summarizing all food preference tests with laboratory rats conducted so far show that products of marketable quality - from organic as compared to conventional production systems - are significantly preferred. The emphasis on 'optimal' production is important, since laboratory rats choose good quality over production system, implying that growing problems entailing a less than good product quality influence the selective behaviour in all cases.

\section{FEEDING TRIALS AS MODELS FOR HUMAN HEALTH RESEARCH}

The results of feeding experiments in the organic field can also be used to optimize production methods if focused on agricultural aspects or to indicate nutritional effects to optimize farm animal feeding strategies. The main purpose of the feeding trials, however, is to ultimately use animals as models for humans. The extrapolation of such animal-based findings to humans has given rise to controversial discussions. On the one hand, it is maintained that extrapolating results obtained from one species to another involves unscientific speculation: on the other hand, all established safety values concerning residues originating from agricultural and veterinary practice are based on animal feeding trials.

In the context of organic quality research, feeding trials are expected to clarify the question of whether production methods could have health-promoting effects. In the last decades, the consumer motivation to buy organic food has shifted from environmental to health concerns. ${ }^{11}$

The environmental advantages of organic farming are well documented and established. The perceived health benefits are based on results from feeding trials concerning fertility parameters and food preferences as described above, but there is still an urgent need to define more specific health biomarkers, relevant to humans, which connect to the specific approach of organic farming. In the perspective of Lady Balfour's vision of 'Healthy soil, healthy plants, healthy people', it has to be kept in mind that human 'health' is a multifactorial conception. The World Health Organization defines health as 'a state of complete physical, mental and social well-being and not merely the absence of disease or infirmity' (Preamble of the constitution of the WHO, 1948). ${ }^{54}$ In more recent years, as in the salutogenesis model developed by Antonovsky in the1970s, health becomes considered as a dynamical state of well-being characterized by the physical, mental and social potential to meet the demands of life according to age, culture and personal responsibility. ${ }^{55,56}$ Disease, therefore, 
would be the lack of this potential. ${ }^{57}$ This is consistent with the organic aim to optimize plants' and animals' natural abilities to be healthy. Human health is then not seen as a state, but a process depending on and influenced by complex interactions between genetic predisposition, environment and society, as well as lifestyle. In clinical terms, health is regarded as the ability of an organism to efficiently respond to challenges and restore wellbeing (homeostasis). The concept and understanding of health has shifted from a static description of well-being to a dynamic reaction to stressors and changes. In quality research in the organic field, the understanding of product quality has undergone a comparable paradigm shift from a static substantial to a dynamic processfocused assessment on a systems level. ${ }^{57}$ Thus the dimension of time has been added to the study of quality, including reactive and interactive processes. From a reductionist view, potential positive health effects of organic food could be attributed to the reduction of synthetic residues as well as the potential increase of healthpromoting compounds. From a more dynamic view, it could be hypothesized that the homeostatic state of the food product contributes to the strengthening of self-regulating properties of the consumer.

It is recognized that nutrition plays an important role in promoting or reducing the organism's ability to cope with potential health threats as well as maintaining a state of wellbeing. Nowadays, cognitive function and behaviour testing are increasingly included in nutritional research. The most important influence of nutrition is based on diet composition, but the quality of the consumed products can have a modulating positive effect. So far, this notion has been attributed to the reduction of synthetic residues as well as the potential increase of healthpromoting compounds. But the outcome of the cited feeding studies comparing test diets of the same nutritive value, only differing in the way of production, necessitates an extension of the quality concept as described, and entails the application of new quality assessment methods.

The interpretation of the results in the consuming organism on a systems level could be facilitated by including modern systems biology methods like metabolomics which, combined with advanced statistical as well as thorough physiological knowledge, can provide insights at regulatory levels. ${ }^{58}$ The challenge for the future will be to combine these methods with the earlier described holistic methods, in development to assess holistic qualities in food products, to search if the hypothesized homeostatic properties of organic food products can be correlated with a balance or imbalance in the consuming organism.

Not all parameters investigated in feeding trials with the described designs are useful biomarkers to be extrapolated to human health. Advantages concerning litter size or food preference provide insight into differences caused by production methods but are less suitable as markers for human health. More recent feeding trials investigating effects on the immune system and nutrigenomic influences can be seen as pioneer studies testing health parameters more directly indicative for human health issues. Thus the aims of future animal feeding trials are the definition of health indicators and the establishment of biomarkers as a basis for intervention studies in humans.

Conclusion of the main characteristics of feeding trials in the organic context, which are guidelines for future projects:

1. Focus either on controlled production methods or on best practice production systems and be clear about the difference.

2. Perform whole food studies in contrast to purified diets.
3. Pay attention to different processing steps in diet preparation.

4. Compose diets according to need.

5. Include modern holistic techniques to approach whole product and whole body concepts.

\section{REFERENCES}

1 Mäder P, Fließbach A, Dubois D, Gunst L, Fried P and Niggli U, Soil fertility and biodiversity in organic farming. Science 296:1694-1697 (2002).

2 Bengtsson J, Ahnström J and Weibull A-C, The effects of organic agriculture on biodiversity and abundance: a meta-analysis. $J$ Appl Ecol 42:261-269 (2004).

3 Reganold J, Sustainability of organic, conventional, and integrated apple orchards. Plant Management Network 2006. [Online]. Crop Management. Available: www.plantmanagementnetwork.org [7 October 2009].

4 Niggli $U$, Leifert C, Alföldi TH, Lück L and Willer H. (eds.) Improving sustainability in organic and low input food production systems. in Proceedings of the 3rd International Congress of the European In-tegrated Project Quality Low Input Food (QLIF). University of Hohenheim, Stuttgart, Germany, March 20-23, 2007. Research Institute of Organic Agriculture FiBL, CH-5070 Frick, Switzerland, ISBN 978-3-03736-003-3 (2007).

5 Lund $V$ and Algers B, Research on animal health and welfare in organic farming: a literature review. Livest Prod Sci 80:55-68 (2003).

6 Balfour EB, The Living Soil. Devin-Adair, New York (1950).

7 Magnusson MK, Arvolaa A, Koivisto Hurstia U-K, Åbergb L and Sjödéna $\mathrm{P}-\mathrm{O}$, Choice of organic foods is related to perceived consequences for human health and to environmentally friendly behaviour. Appetite 40:109-117 (2003).

8 By-laws FQH. [Online]. Available: http://www.organicfghresearch. org/about_fah/bylaws_standingrules.html\#laws [7 October 2009].

9 Kaur C and Kapoor HC, Antioxidants in fruits and vegetables: the millennium's health. Int J Food Sci Technol 36:703-725 (2001).

10 Bazza LA, He J, Ogden LG, Loria CM, Vupputuri S, Myers L, et al, Fruit and vegetable intake and risk of cardiovascular disease in US adults: the first National Health and Nutrition Examination Survey Epidemiologic Follow-up Study. Am J Clin Nutr 76:93-99 (2002).

11 Gundgaard J, Nielsen JN, Olsen J and Sørensen J, Increased intake of fruit and vegetables: estimation of impact in terms of life expectancy and healthcare costs. Publ Health Nutr 6:25-30 (2003).

12 Barkholt V, Hansen SL, Kobæk-Larsen M, Christensen LP, Kharazmi A, Jespersen $\mathrm{L}$, et al, Health promoting compounds in vegetables and fruits: a systematic approach for identifying plant components with impact on human health. Trends Food Sci Technol 15:384-393 (2004).

13 Lock K, Pomerleau J, Causer L, Altmann DR and McKee M, The global burden of disease attributable to low consumption of fruit and vegetables: implications for the global strategy on diet. Bull World Health Org 83:100-108 (2005).

14 Gitenay D, Lyan B, Rambeau M, Rambeau M, Mazur A and Rock E, Comparison of lycopene and tomato effects on biomarkers of oxidative stress in vitamin E deficient rats. Eur J Nutr 46:468-475 (2007).

15 Tatsioni A, Bonitsis NG and loannidis JPA, (2007): Persistence of contradicted claims in the literature. J Am Med Assoc 298:2517-2526 (2007).

16 Howes RM, Cardiovascular Disease: (A New Paradigm) and Oxygen Free Radical Mythology. Free Radical Publishing (2006) Available: http://www.thepundit.com/downloads/cardiovascular.pdf.

17 Miller ER, Pastor-Barriuso R, Dalal D, Riemersma RA, Appel $\amalg$ and Guallar E, Meta-analysis: high-dosage vitamin E supplementation may increase all-cause mortality. Ann Int Med 142:37-46 (2005).

18 Bjelakovic G, Nikolova D, Simonetti RG and Gluud C, Antioxidant supplements for prevention of gastrointestinal cancers: a systematic review and meta-analysis. Lancet 364:1219-1228 (2004).

19 Vivekananthan DP, Penn MS, Sapp SK, Hsu A and Topol EJ, Use of antioxidant vitamins for the prevention of cardiovascular disease: meta-analysis of randomised trials. Lancet 361:2017-2023 (2003).

20 Baars $\mathrm{E}$ and Baars T, Towards a philosophical underpinning of the holistic concept of integrity of organisms within organic agriculture. Wageningen J Life Sci 54-55:463-477 (2007). 
21 Kahl J, Busscher N and Meier-Ploeger A, Neue Ansätze zur Erfassung ökologischer Lebensmittelqualität [New approaches to measure organic food quality]. Ökologie \& Landbau 127:26-28 (2003).

22 Strube J and Stolz P, Fluorescence excitation spectroscopy for the evaluation of seeds, in Proceedings of the 13th International IFOAM Scientific Conference, ed. by Alföldi T, Lockeretz W and Niggli U. Basel, pp. 306-309 (2000).

23 Przystalski M, Osman A, Thiemt E, Rolland B, Ericson L, Østergård H, et al, Comparing the performance of cereal varieties in organic and non-organic cropping systems in different European countries. Euphytica 163:417-433 (2008).

24 Bose KSC and Agrawal BK, Effect of lycopene from cooked tomatoes on serum antioxidant enzymes, lipid peroxidation rate and lipid profile in coronary heart disease. Singapore Med J 48:415-420 (2007).

25 CORE project (2007-2020): quality analysis of critical control points within the whole food chain and their impact on food quality, safety and health (QACCP). [Online]. Available: http://qaccp. coreportal.org/[7 October 2009].

26 Williams CM, Nutritional quality of organic food: shades of grey or shades of green? Proc Nutr Soc 61:19-24 (2002).

27 Velimirov A, Integrative methods of product quality assessment in connection with the p-value-determination ( 3 examples: food preference test, sensory evaluation and self-decomposition test). $J$ Hortic Sci Biotechnol 31:17-21 (2004).

28 Wöse K, Lange D, Boess C and Bögl KW, Ökologisch und konventionell erzeugte Lebensmittel im Vergleich. Eine Literaturstudie, Teil 2 (BGVV-Heft 5), 372-758, Hrsg.: Bundesinstitut für gesundheitlichen Verbraucherschutz und Veterinärmedizin. Berlin.

29 McCarrison R, The effect of manurial conditions on the nutritive and vitamin values of millet and wheat. Ind J Med Res 14:351 - 378 (1926).

30 Pfeiffer $E$, Vergleichender Fütterungsversuch mit mineralisch gedüngtem und biologisch-dynamisch gedüngtem Getreide. Demeter 6:87-89 (1931).

31 Pfeiffer $E$ and Sabarth $E$, Vergleichender Fütterungsversuch mit Hühnern. Demeter 7:198-200 (1932).

32 Scheunert A, Vergleichende Untersuchung der physiologischen Wirkung fortgesetzten Genusses von Nahrungsmitteln, die mit und ohne Handelsdünger gezogen sind. Angewandte Chemie 48:42-46 (1935).

33 Aehnelt E and Hahn J, Fruchtbarkeit der Tiere: eine Möglichkeit zur biologischen Qualitätsprüfung von Futter- und Nahrungsmitteln. Tierärztl Umsch 4:155-170 (1973).

34 Bram L, (1974): Über den Einfluß von Fütterungsfaktoren auf den Ascorbinsäuregehalt und den histologischen Aufbau der Nebennierenrinde von weiblichen Kaninchen unter besonderer Berücksichtigung der Beziehungen zwischen Nebennierenrindenfunktion und Fruchtbarkeit. Inaugural dissertation, Tierärztliche Hochschule Hannover (1974).

35 Miller DS and Dema IS, (1958): Nutritive value of wheat from the Rothamsted Broadbalk field, in Proc Nutr Soc 17:xliv-xlv (1958).

36 Alter G, Über den Einfluß von Fütterungsfaktoren auf das Fruchtbarkeitsgeschehen. Den Ascorbinsäuregehalt und den histologischen Aufbau der Ovarien von weiblichen Kaninchen. Inaugural dissertation, Tierärztliche Hochschule Hannover (1978).

37 Neudecker C, Düngung und Qualität von Lebensmitteln: Tierfütterungsversuche mit mineralisch und organisch gedüngten Kartoffeln und Möhren, in Landbaumethoden und Nahrungsqualität: Materialien und Berichte No. 60). Akademie für Politische Bildung, Tutzing, Germany, pp. 110-125 (1987).

38 Rembiałkowska E, Hallmann E, Rusaczonek A, Bennett RN, Brandt $\mathrm{K}$ Lueck $\mathrm{L}$, etal, The content of bioactive compounds in rat experimental diets based on organic, low-input and conventional plant materials, in Improving Sustainability in Organic and Low Input Food Production Systems: Proceedings of the 3rd International Congress of the European Integrated Project Quality Low Input Food (QLIF), University of Hohenheim, Germany, 20-23 March (2007). pp. $112-117$.

39 Gottschewskil GHM, Neue Möglichkeiten zur größeren Effizienz der toxikologischen Prüfung von Pestiziden, Rückständen und Herbiziden. Plant Foods Hum Nutr 25:21-42 (1975).
40 Edelmüller I, Untersuchungen zur Qualitätserfassung von Produkten aus unterschiedlichen Anbausystemen (biologisch-dynamisch bzw. konventionell) mittels Fütterungsversuchen an Kaninchen. Dissertation, Universität Wien (1984).

41 Staiger D, Einfluß konventionell und biologisch-dynamisch angebauten Futters auf Fruchtbarkeit, allgemeinen Gesundheitszustand und Fleischqualität beim Hauskaninchen. Dissertation, Universität Bonn (1986).

42 Velimirov A, Plochberger K, Huspeka U and Schott W, The influence of biologically and conventionally cultivated food on the fertility of rats. Biol Agric Hortic 8:325-337 (1992).

43 Lauridsen C, Yong C, Halekoh U, Bügel SH, Brandt K, Christensen LP, et al, Rats show differences in some biomarkers of health when eating diets based on ingredients produced with three different cultivation strategies. J Sci Food Agric 88:720-732 (2008).

44 Huber M (ed.), Organic, More Healthy? A Search for Biomarkers of Potential Health Effects Induced by Organic Products, Investigated in a Chicken Model. Louis Bolk Institute, Driebergen (2007).

45 Barańska A, Skwarło-Sońta L, Rembiałkowska E, Brandt K, Lueck L and Leifert $C$, The effect of short term feeding with organic and conventional diets on selected immune parameters in rat, in Improving Sustainability in Organic and Low Input Food Production Systems: Proceedings of the 3rd International Congress of the European Integrated Project Quality Low Input Food (QLIF), University of Hohenheim, Germany, 20-23 March (2007). pp. 108-111.

46 Sclafani A, How food preferences are learned: laboratory animal models. Proc Nutr Soc 54:419-427 (1995).

47 Velimirov A, Biogram and quality count as suitable indicators of product quality, in Wissenschaftstagung zum Ökologischen Landbau: Ökologischer Landbau der Zukunft, Beiträge zur 7, ed. by B. Freyer (2003). pp. 233-236.

48 Velimirov A, The consistently superior quality of carrots from one organic farm in Austria compared with conventional farms, in Proceedings of the 15th IFOAM Organic World Congress: Researching and Shaping Sustainable Systems, ed. by Köpke U, Niggli U, Neuhoff D, Cornish P, Lockeretz W and Willer H, Adelaide, 21-23 September (2005).

49 Pfeiffer E, Die Fruchtbarkeit der Erde (5th edn). Rudolf Geering, Dornach (1969).

50 Plochberger K, Feeding experiments. a criterion for quality estimation of biologically and conventionally produced foods. Agric Ecosyst Environ 27:419-428 (1989).

51 Plochberger $\mathrm{K}$ and Velimirov $\mathrm{A}$, Are food preference tests with laboratory rats a proper method for evaluating nutritional quality? Biol Agric Hortic 8:221 - 233 (1992).

52 Velimirov A, Reproductive health of rats, in Proceedings of the 1st Scientific FQH Conference: What We Achieved - Where We Will Go, ed. by International Research Association for Organic Food Quality and Health, 28-29 November. Research Institute of Organic Agriculture (FiBL), Frick, Switzerland (2005).

53 Yong C, Halekoh U, Jørgensen $\mathrm{H}$ and Lauriden C, Dependent on dietary treatments of mothers, rats showed individual preference of diets containing ingredients produced with different cultivation strategies. J Anim Feed Sci 14:715-726.

54 WHO (1948). [Online]. Available: http://www.who.int/about/defini tion/en/print.html [7 October 2009].

55 Antonovsky A, Health, Stress and Coping: New Perspectives on Mental and Physical Well-Being. Jossey-Bass, San Francisco, CA (1979).

56 Antonovsky A, Unraveling the Mystery of Health: How People Manage Stress and Stay Well. Jossey-Bass, San Francisco, CA (1987).

57 Bloksma J, Northolt M, Huber M, Burgt GJ van der and Vijver LPL van de, A new food quality concept based on life processes, in Handbook of Organic Food Safety and Quality, ed. by Cooper J, Niggli U and Leiffert C. Woodhead, Cambridge, UK (2007).

58 Van der Greef SM, Juhasz P, Adourian A, Plasterer T, Verheij ER and McBurney RN, The art and practice of systems biology in medicine: mapping patterns of relationships. J Proteome Res 6:1540-1559 (2007). 